\title{
M olluscan Fauna of Surha Tal, District - Ballia (U. P.), India
}

\author{
Rajnish K umar Sharma* and Nirupama Agrawal \\ Department of Zoology, University of Lucknow, Lucknow (U.P.), INDIA \\ *Corresponding author. E-mail: rajnish.enviro.80@gmail.com
}

Abstract: Diversity of molluscan fauna of Surha Tal, district Ballia (U.P.) was studied during 2006-08.Twenty species of molluscs were collected. Of these, fourteen species of six genera belong to class Gastropoda, families Viviparidae, Pilidae, Thiaridae, Lymnaeidae and Planorbidae; six species belonging to three genera are of families of the class Bivalvia; Unionidae, Amblemidae and Corbiculidae.

Keywords: Mollusc fauna, Surha Tal, Ballia (U.P.)

\section{INTRODUCTION}

The present investigation on Molluscan fauna was carried out during April, 2006- March, 2008. It deals with the commonly occurring molluscs of Surha Tal, district Ballia (U. P.). It is a perennial lake, situated between the parallels 25 $48^{\prime}$ 'North and 2505' North Longitude and $84^{\circ} 8^{\prime}$ East and $24^{\circ} 12^{\prime}$ East, located about $13 \mathrm{~km}$ north of Ballia town of U.P. It covers an area of about 20 Sq. miles ie., 9450 Acres. In summer, this area shrinks to about 2774 Acres (Pandey et al., 2010). Fresh water molluscs play a significant role in aquatic ecosystem and some of them are edible as well. As is well known, some of them act as intermediate hosts of various parasites. Shells of many are also used in making fancy articles thus of great economic value. Since not much work has

Table 1. A list of collected molluscs from Surha Tal, Ballia.

\begin{tabular}{|c|c|c|}
\hline Class & Family & Scientific Name \\
\hline \multirow[t]{14}{*}{ Gastropoda } & Viviparidae & 1. Bellamya bengalensis (Lamarck, 1822) \\
\hline & & 2. Bellamya bengalensis form typica (Lamarck, 1822) \\
\hline & & 3. Bellamya bengalensis form mandiensis (Kobelt, 1909) \\
\hline & & 4. Bellamya dissimilis (Muller, 1774) \\
\hline & Pilidae & 1. Pila globosa (Swainson, 1822) \\
\hline & & 2. Pila sctuta (Swainson, 1848) \\
\hline & Thiaridae & 1. Thiara (Thiara) rudis (Lea, 1850) \\
\hline & & 2. Thiara (M alanoides) tuberculata (Muller, 1774) \\
\hline & Lymnaeidae & 1. L. (P seud.) acuminata form typica (Lamarck, 1822) \\
\hline & & 2. L. (P seud.) acuminata form chlamys (Benson, 1836) \\
\hline & & 3. L. (P seud.) acuminata form patula (Troschel, 1837) \\
\hline & & 4. L. (P seud.) acuminata form rufescens (Gray, 1822) \\
\hline & Planorbidae & 1. Gyraulus convexiusculus (Hutton, 1849) \\
\hline & & 2. Indoplanorbis exustus (Deshayes, 1834) \\
\hline \multirow[t]{6}{*}{ Bivalvia } & Unionidae & 1. Lamellidens marginalis (Lamarck, 1819) \\
\hline & & 2. Lamellidens corrianus (Lea, 1834) \\
\hline & Amblemidae & 1. Parreysia (Parreysia) corugata (Mueller, 1774) \\
\hline & & 2. Parreysia (Parreysia) favidens (Benson, 1862) \\
\hline & & 3. P. (P arreysia) favidens var. marcens (Benson, 1862) \\
\hline & Corbiculidae & 1. Corbicula striatella (Deshayes, 1854) \\
\hline
\end{tabular}

ISSN : 0974-9411(Print), 2231-5209 (Online) All Rights Reserved @ Applied and Natural Science Foundation. www.ansfoundation.org been done on the molluscan fauna of this lake, the present work was undertaken.

\section{MATERIALS AND METHODS}

The molluscs for the present work were collected using gloves, by boats, nylon scoop net, with the help of local fisherman, morning and late evening hours, as the animals settle down during bright Sun. The collected samples were washed and preserved in 5\% formalin, brought to the laboratory and studied. Some specimens of each of them were kept alive for several weeks in the laboratory in glass aquaria and earthen pots. They were fed on lettuce. Identification was carried out with the help of $\mathrm{H}$ andbook of F reshwater Molluscs of India by Subba Rao (1989) and $\mathrm{H}$ andbook on Indian freshwater M oll uscs by Ramakrishna and Dey (2007). Specimens were also taken to the Zoological Survey of India (Z.S.I.) Kolkata
2. Bellamya bengalensis form typica (Lamarck, 1822)

4. Bellamya dissimilis (Muller, 1774)

1. Thiara (Thiara) rudis (Lea, 1850)

. Thiara (Malanoides) tuberculata (Muller, 1774)

(Pseud.) acuminata form typica (Lamarck, 1822)

3. L. (P seud) acuminata form patula (Troschel, 1837)

4. L. (P seud.) acuminata form rufescens (Gray, 1822)

3. P. (Parreysia) favidens var. marcens (Benson, 1862) 


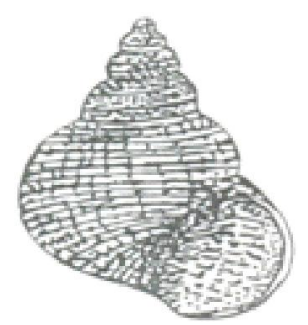

(1)

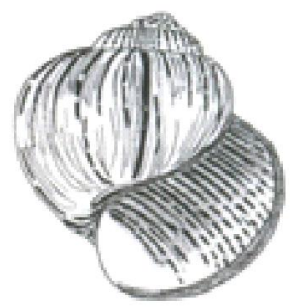

(6)

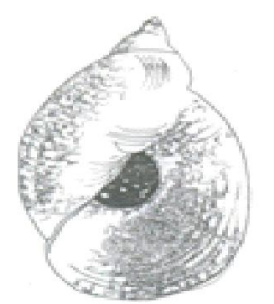

(11)

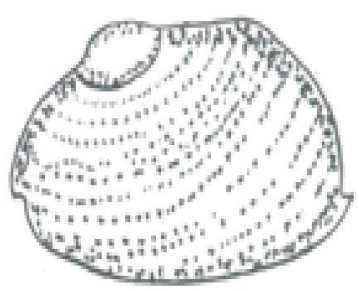

(16)

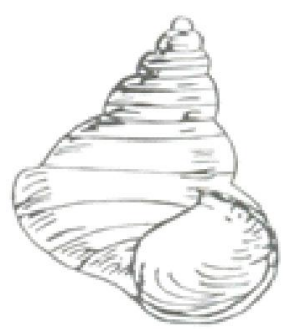

(2)

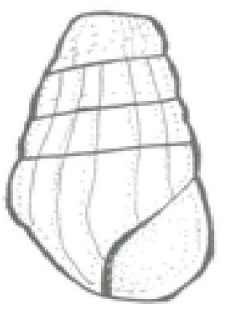

(7)

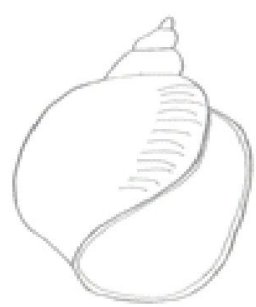

(12)

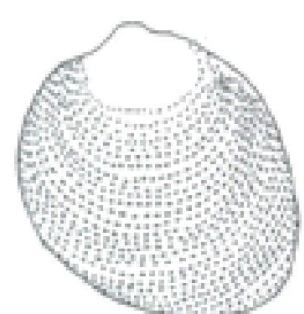

(17)

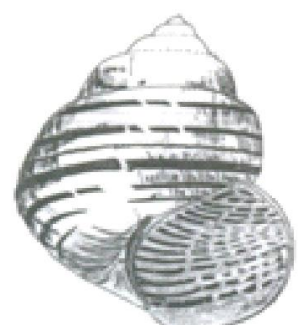

(3)

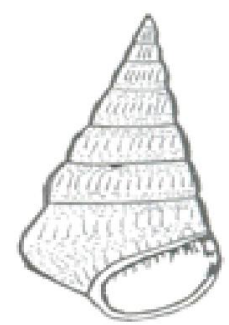

(8)

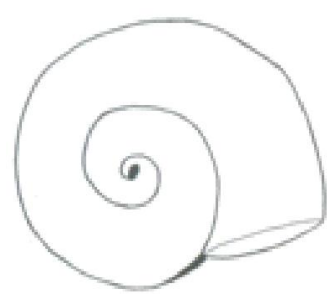

(13)

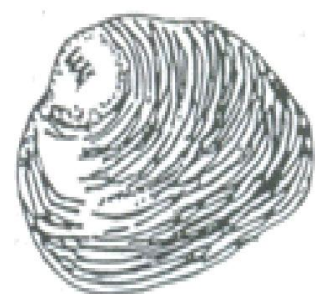

(18)

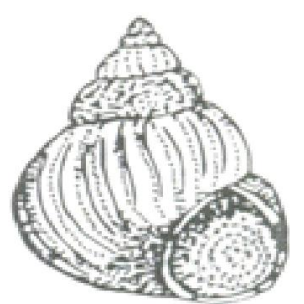

(4)

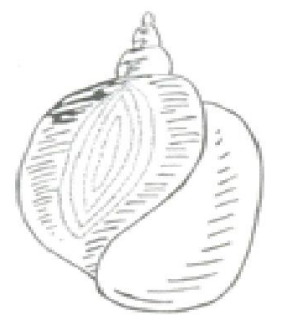

(9)

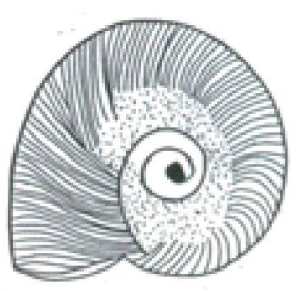

(14)

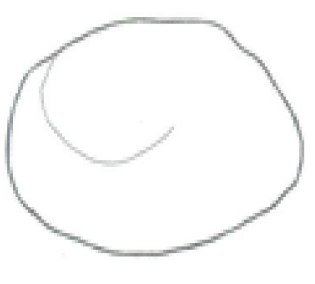

(19)

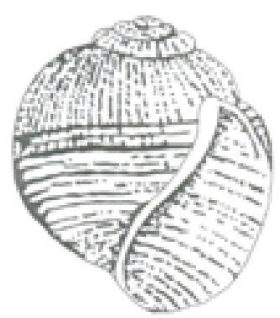

(5)

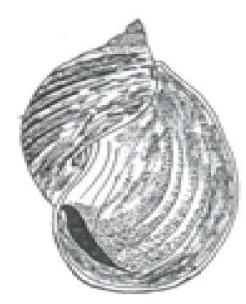

(10)

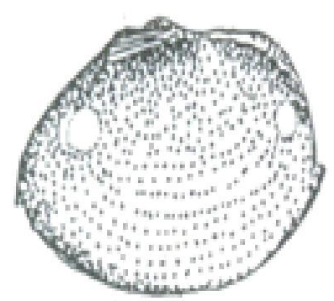

(15)

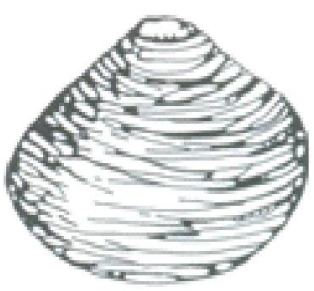

(20)

Figs. 1-20 Types of M olluscs in Surha Tal: 1. Bellamya bengalensis (Lamarck, 1822), 2. B. bengalensis form typica (Lamarck, 1822), 3. B. bengalensis form mandiensis (K obelt, 1909), 4. B. dissimilis (M uller, 1744), 5. Pila globosa (Swainson, 1822), 6. P. sctuta (Swainson. 1848), 7. Thiara (Thiara) rudis (Lea, 1850), 8. T. (Malanoides) tuberculata (Muller, 1774), 9. Lymnaea (Pseudusuccinea) acuminata form typica (Lamarck, 1822), 10. Lymnaea (Pseudusuccinea) acuminata form chlamys (Benson, 1836), 11. L. (Pseudusuccinea) acuminate form patula (Troschel, 1837), 12. L. (Pseudusuccinea) acuminata form rufescens (Gray, 1822), 13. Gyraulus convexi usculus (Hutton, 1849), 14. Indoplanorbis exustus (D eshayes, 1834), 15. Lamellidens marginalis (Lamarck, 1819), 16. L. corrianus (Lea, 1834), 17. Parreysia (Parreysia) corugata (M ueller, 1774), 18. P. (Parreysia) favidens (Benson, 1862), 19. P. (Parreysia) favidens var. marcens (Benson, 1862), 20. Corbicula striatella (D eshayes, 1854).

for confirmation and deposition. A list of collected molluscs is given in Table 1.

\section{RESULTS AND DISCUSSION}

This is a record of molluscan fauna of Surha Tal, during two years. Twenty species of molluscs were collected. Of these, fourteen species of six genera belonged to class Gastropoda, families Viviparidae, Pilidae, Thiaridae, Lymnaeidae and Planorbidae; six species belonging to three genera are of families of the class Bivalvia; Unionidae, Amblemidae and Corbiculidae. The earlier work is that of Lakshman (1976) who has reported only Pila globosa, Viviporus bengalensis, Viviporus dissimilis, Lamellidens marginalis, Lymnaea luteola, Lymnaea acuminate, Indoplanorbis exustus, Alocinma oricula and $G$ yraulus convexiusculus, from this wetland of district Ballia, U.P. Specimens of Alocinma oricula and Lymnaea luteola could not be obtained inspite of several efforts. Moreover, Parreysia (Parreysia) corugata, Parreysia (Parreysia) favidens Parreysia favidens var. marcens and Corbicula striatella are rarely 
found. Molluscs play a vital role in the freshwater environment and are, therefore, a part of freshwater community, having important role in food chain. They are important food for human and also serve as vectors of many diseases of live stock and man. Reckless killing of these animals are to be controlled in this region. However, they are less explored ecologically which can be a part of future study.

\section{ACKNOWLEDGEMENTS}

The authors are indebted to Dr. Ashok Kumar Singh,
Deputy Director, ZSI Kolkata for the help in identification.

\section{REFERENCES}

Lakshman, Ram (1976) Suraha lake, its Ecology and Fisheries. The Ind. J . of Zoot. 17: 31-51.

Ramakrishna \& Dey, A. (2007) H andbook on Indian freshwater M olluscs, Zoological Survey of India, Kolkata :1-399.

Subba Rao, N. V. (1989). Handbook: Freshwater M olluscs of India, Zoological Survey of India, Kolkata : 1-289.

Pandey, K.C. Agrawal, N. and Sharma, R.K. (2010) Fish fauna of Surha Tal of Ballia (U. P.), India J . App. \& Nat. Science, 2(1): 22-25. 